\title{
Comparative Analysis of Perfectionism and Value-Semantic Barriers of the Student's Personality
}

\author{
Galina Epanchintseva ${ }^{1}$, Irina Bukhtiyarova ${ }^{2}$, Natalia Panich ${ }^{2}$ \\ ${ }^{1}$ Orenburg State University, Orenburg, Russian Federation \\ ${ }^{2}$ Lomonosov Moscow State University, 1 Leninskie Gory, Moscow 119991, Russian Federation
}

\begin{abstract}
The research compares perfectionism as a personal quality and its value-semantic barriers during the acquisition of the first professional skills in order to provide psychological support for social adaptation. It is argued that timely diagnosis of such condition can clarify the necessary psychotherapeutic interventions. A program of point studies to present new empirical data and formulate new relationships between structural and nuclear characteristics of the individual was formalized. The classical quasi-experimental approach of D. Campbell was used for analysis. The achieved results can help to form a more critical scientific view on the studied problem.
\end{abstract}

Keywords - Behaviour coping, perfectionism, personality, student, value-semantic barriers.

\section{Introduction}

Perfectionism is a fairly young personality trait to study, which still does not have a single definition, although for some reasons sources as a concept have been around since medieval times and it can be traced in the philosophy of I. Kant, F. Nietzsche and G. Leibniz [1]. Problem the study of perfectionism

DOI: 10.18421/TEM101-55

https://doi.org/10.18421/TEM101-55

Corresponding author: Galina Epanchintseva, Orenburg State University, 13 Pobedy Ave., Orenburg 460000, Russian Federation.

Email: epanchintseva_g@rambler.ru

Received: 18 September 2020.

Revised: 04 February 2021.

Accepted: 11 February 2021.

Published: 27 February 2021.

(cc) BY-NC-ND(C) 2021 Galina Epanchintseva, Irina Bukhtiyarova \& Natalia Panich; published by UIKTEN. This work is licensed under the Creative Commons AttributionNonCommercial-NoDerivs 4.0 License.

The article is published with Open Access at www.temjournal.com has been and is the focus of a number of studies scientists from Europe, the USA, Russia (A. Adler, M. Hollender, M. Clark, R. Frost, D. Burns, P. Hewitt, G. Flett, A.W. Kruglanski, S.N. Enikolopov, E.P. Ermolaeva, V.A. Yasnaya, A.M Ulanovskiy, I.V. Abakumova and others) [1], [2], [3], [4], [5], [6], [7], [8], [9], [10]. Philosophers believed that perfectionism is the belief that improvement is a main goal that should be sought by both the individual and the individual all of humanity. Karen Horney in the middle of the twentieth century defined perfectionism in the tradition of psychoanalysis as a narcissistic personality trait an organization where the ideal Self is born, as a way to hide the weak and the helpless real Self [11], [12]. Formation of the definition and distinctive features signs for diagnosing perfectionism began in the 6080 s of the XX century, within the framework of clinical psychology and psychotherapy [6], [8], [13]. One of the first the definition belongs to $M$. Hollender and reads as follows: "perfectionism is the daily practice of making demands on yourself higher quality of performance than required circumstances" [1]. Perfectionism was seen, as a construct with the only parameter is "excessively high personal requirements" [10], [14].

In the $1990 \mathrm{~s}$, thanks to three groups of foreign researchers' ideas about the structure of perfectionism has been greatly expanded. These were British clinical psychologists under the direction of Frost, Canadian scientists, led by Hewitt, and American scientists. They unanimously wrote that perfectionism it is a multi-dimensional construct and has not the only one distinctive parameter [5], [7], [15]. Subsequent research allowed identifying a wide range of behavioral patterns of personality that have average and high values of perfectionism [13], [16].

Scientists of the American group as the main parameters' perfectionism was highlighted: high standards, a tendency to order, anxiety, procrastination, and problems in interpersonal relationships [8]. 
Frost and his British colleagues in the structure of perfectionism included parameters such as high personal standards, which generated fluctuations in self-esteem and chronic dissatisfaction with their own overly concerned [5]. Noted by Frost's colleagues' positions have high values of perfectionism: not accepting the fact of making mistakes in activities that lead to a loss of faith in own forces, excessive criticism, creating situations organization of the order of execution, which sometimes leads to absurdity the most organized activity [5].

Canadian researchers have put forward an alternative view of the structure of perfectionism [7]. First of all, the perfectionist puts forward a super task. He has to be better than others and better than himself; he cannot be wrong, he is perfect. The perfectionist makes excessive demands on those close to them and their significant others. He constantly evaluates the behavior and actions of others and, as a result, generates in himself distrust and hostility towards other people. Scientists in this group also suggested that perfectionists have high demands on the world as a whole [8]. World problems have to obey the tendency of adequate, timely assessment and unswerving correct solution of all problems. However, this parameter has not been included in the measuring tool as it has not been empirically validated [8], [17]. Further, scientists of this direction noted that empirical studies have revealed a high correlation of the locus of control with a high need for approval, fear of negative assessment [18], [19]. It was also found that high values of perfectionism reflect the individual's belief that other people are very strict in their expectations and cannot earn the encouragement of significant others. Representatives of the cognitive approach (D. Dunkley, K. Blankstein, R. Masheb, C. Grilo, R. Frost, P. Marten, P. Hewitt, and G. Flett, etc. [10], [16]) continue to consider perfectionism as a multidimensional construct. Proponents of the behavioral direction [20] are more focused on revealing the mechanisms of work of perfectionism as a construct than its parameters. Our research aimed at identifying the relationship between perfectionism and value-meaning barriers in the professional formation of the personality caused the need to present a theoretical thesaurus of this problem. It was found that the problem of valuesense barriers in studies of recent years is analyzed mainly in the context of client-centered therapy E. Fromm [21], author of existential psychology and psychotherapy V. Frankl [18] or the psychological organization of the educational and communicative sphere (A.A. Osipova [22], A.A Zelenov [22], [23], O.S. Alekseeva [24], E.P. Ermolaeva [9], E.S. Zorina [23]). In connection with our author's inclusion in this research topic, we believe that a new paradigm view of postmodern psychology is needed. V.Ye. Klochko, S. Maddi, D.A. Leontiev, I.A. Vasiliev, V.L. Popluzhny, O.K. Tikhomirov recognize the category of "meaning" as a central psychological construct [19], [25], [26], [27]. According to A.A. Orlov and A.A. Voskresenskiy, the concept of "meaning" is the trigger of an objectively given situation in the most thought activity, which independently of its subjects acquires value dimensions [14], [28]. The reflection and processing of external and internal stimuli is subject only to what has meaning and value for personality [29]. By its theoretical premise, we argue that healthy perfectionism, as a multidimensional personality characteristic, contributes to overcoming the valuemeaning barriers of a novice professional.

\section{Methodology}

We selected the following research methods:

1) theoretical analysis of scientific literature, transpective analysis;

2) standardized test method;

3) method of mathematical statistics: Spearman rank correlation, non-parametric Mann-Whitney U-criterion.

The authors analyzed an experimental diagnostic tool used for the study of perfectionism: the scale of "out-of-reach perfection" (Almost Perfect Scale, APS), Hewitt-Flett Multidimensional Perfectionism Scale [7], Multivariate Frost Perfectionism Scale (Multidimensional Perfectionism Scale, MPS-F) [5], PANPS Technique (Positive and Negative Perfectionism Scale). Next, we determined the methodology of the study. The main study method was the Hewitt-Flett Multidimensional Perfectionism Scale. Preference for this technique was based on its adaptability on a Russian-language sample. A.A. Zolotareva's differential test of perfectionism played the role of an additional technique that studies the phenomenon of perfectionism [30]. Coping strategies were investigated by E. Heim's valid and reliable coping strategy methodology [31]. The study of value-meaning barriers was studied according to the methodology "Level of psychological barriers" of A.V. Massanov [32], and "Test of LSS" by D.A. Leontiev [26].

The authors conducted the study on a representative sample:

Our study involved 112 respondents aged 20 to 24 years, among them 47 female respondents, 65 male respondents. All respondents are students of Orenburg State University, full-time department. Respondents receive the specialty of a psychologist, the specialty of a journalist. Respondents live in the 
city of Orenburg in urban apartments. Marital status - unmarried (97), married (15). Students are successful in learning, active in social life. Respondents were assigned ciphers. These study ciphers are stored during processing and discussion of the study results.

\section{Results and Discussion}

In the tradition of the theory of quasi experimental study of D. Campbell [33],

we conducted a number of correlation studies, presented below.

The following are the results of a comparative author's study of the level of psychological barriers and indicators of perfectionism using the A.V. Massanov technique and the Hewitt-Flett perfectionism test.

Table 1. Correlation analysis of the level of psychological barriers methods of A.V. Massanov and the Hewitt-Flett perfectionism test

\begin{tabular}{||ccccc||}
\hline \multicolumn{5}{|c||}{$\begin{array}{c}\text { Spearman correlation coefficients of the level of psychological barriers of A.V. Massanov and the } \\
\text { Hewitt-Flett perfectionism test scales }\end{array}$} \\
\hline & Self-orientation & Focus on other & $\begin{array}{c}\text { Socially prescribed } \\
\text { perfectio-nism }\end{array}$ & $\begin{array}{c}\text { Integral scale of } \\
\text { perfectionism }\end{array}$ \\
Level of psychological barriers & .018 & $.425^{*}$ & .208 & .183 \\
\hline
\end{tabular}

$*$ statistically significant $(\mathrm{p} \leq 0.05)$

We allow these results to be interpreted as follows. From the Table, we see that a moderate, direct relationship was found between the level of psychological barriers and orientation to others, that is, the tendency to make demands on others. Based on the result, we assume that in the group we study, respondents consider external factors, or rather people around them, to be the reason for their failures and difficulties in anything. Mann-Whitney's U-test showed no statistical differences between boys and girls.

When studying the correlation between the results of tests measuring the level of psychological barriers of A.V. Massanov and the differential test of perfectionism of A.A. Zolotareva, we obtained the data reflected in Table 2. The following are the results of a comparative author's study.

Table 2. Correlation analysis of the level of psychological barriers of A.V. Massanov's method and A. A. Zolotareva's perfectionism test

\begin{tabular}{||lccc||}
\hline \multicolumn{3}{|c|}{$\begin{array}{l}\text { Spearman correlation coefficients the level of psychological barriers methods of A.V. Massanov and the } \\
\text { perfectionism test of A.A. Zolotareva }\end{array}$} \\
\hline \multirow{2}{*}{ Level of psychological barriers } & Normal perfectionism & Pathological perfectionism & General perfectionism \\
\hline
\end{tabular}

* statistically significant $(\mathrm{p} \leq 0.01)$

We allow these results to be interpreted as follows. From the Table, we see that a high, inverse relationship was found between the level of psychological barriers and normal perfectionism (adaptive, constructive, and healthy). Given the result, we confirmed the research of scientists who wrote about healthy perfectionism as a factor in overcoming psychological barriers and, as a result, some kind of prevention of psychosomatic diseases. Indeed, in the process of achieving the goals set, it is necessary to overcome certain difficulties and obstacles including of a psychological nature, and without the determination and perseverance of a person who has constructive perfectionism, this overcoming is extremely difficult. Mann-Whitney's U-test showed no statistical differences between boys and girls.

When studying the correlation between the results of tests measuring the level of psychological barriers of A.V. Massanov and the test of LMS D.A. Leontiev, we received the data reflected in Table 3. The following are the results of a comparative author's study. 
Table 3. Correlation analysis of the level of psychological barriers of A.V. Massanov's method and D. A. Leontiev's SGO test

\begin{tabular}{||ccccccc|}
\hline \multicolumn{8}{|c|}{ Spearman's correlation coefficients of the level of psychological barriers of A.V. Massanov's } \\
methodology and D. A.Leontiev's SGO test
\end{tabular}

* statistically significant $(\mathrm{p} \leq 0.01)$

We allow these results to be interpreted as follows. Table 3 shows a high, inverse relationship between the level of psychological barriers and meaningful orientations according to the results of the study of the test of LSS D.A. Leontiev. This confirms the research and reasoning of psychologists that adaptive value-meaning orientations of the personality and a positive attitude to their past, present and future lives - as well as normal perfectionism serve as a prevention of the development of psychological barriers. Mann-Whitney's U-test showed no statistical differences between boys and girls.

When studying the correlation between the results of the tests of the differential test of A.A. Zolotareva and the technique of coping strategies of E. Heim, we received new empirical data presented in Table 4.

Table 4. Correlation analysis of A.A. Zolotareva's differential test and E. Heim's coping strategy methodology

\begin{tabular}{|c|c|c|c|}
\hline \multicolumn{4}{|c|}{$\begin{array}{l}\text { Spearman's correlation coefficients of the } \\
\text { differential test of perfectionism A.A. Zolotareva } \\
\text { and E. Heim's coping strategies }\end{array}$} \\
\hline & $\begin{array}{l}\text { Cognitive } \\
\text { coping } \\
\text { strategies }\end{array}$ & $\begin{array}{l}\text { Emotional } \\
\text { coping } \\
\text { strategies }\end{array}$ & $\begin{array}{l}\text { Behaviora } \\
\text { coping } \\
\text { strategies }\end{array}$ \\
\hline $\begin{array}{l}\text { Normal } \\
\text { perfectionism }\end{array}$ & $.343 *$ & .061 & .241 \\
\hline $\begin{array}{l}\text { Pathological } \\
\text { perfectionism }\end{array}$ & .068 & .077 & .182 \\
\hline $\begin{array}{l}\text { General } \\
\text { perfectionism }\end{array}$ & .225 & .129 & $.382 * *$ \\
\hline
\end{tabular}

* statistically significant $(\mathrm{p} \leq 0.1)$

** statistically significant $(\mathrm{p} \leq 0.05)$

In examining the correlation between Hewitt-Flett multivariate perfectionism scale scores and Heim's coping strategy methodology, we obtained the new empirical data presented in Table 5.
Table 5. Correlation analysis of the multidimensional scale of Hewitt-Flett perfectionism and the method of coping strategies by E. Heim

\begin{tabular}{|c|c|c|c|}
\hline \multicolumn{4}{|c|}{$\begin{array}{c}\text { Spearman's correlation coefficients of the Hewitt-Flatt } \\
\text { multidimensional perfectionism scale and Heim's coping } \\
\text { strategy methods }\end{array}$} \\
\hline \multirow{4}{*}{$\begin{array}{l}\text { Self-orientation } \\
\text { Orientation } \\
\text { towards others } \\
\text { Socially } \\
\text { prescribed } \\
\text { perfectionism }\end{array}$} & $\begin{array}{l}\text { Cognitive } \\
\text { coping } \\
\text { strategies }\end{array}$ & $\begin{array}{l}\text { Emotional } \\
\text { coping } \\
\text { strategies }\end{array}$ & $\begin{array}{l}\text { Behaviora } \\
\text { l coping } \\
\text { strategies }\end{array}$ \\
\hline & .034 & .174 & .224 \\
\hline & $.492 * *$ & $.046^{*}$ & .199 \\
\hline & .128 & .102 & .024 \\
\hline $\begin{array}{l}\text { Integral scale of } \\
\text { perfectionism }\end{array}$ & .114 & .148 & .157 \\
\hline
\end{tabular}

We allow these results of correlation studies to be interpreted as follows. Having studied the cash of the mutual influence of the features of perfectionism and the choice of one or another coping behavior among respondents - we received the data presented in Tables 4 and 5. The correlation results showed a moderate, inverse relationship between general perfectionism and behavioral coping strategies and an inverse trend between normal perfectionism and cognitive coping strategies in Table 4. This means that the higher the level of general or normal perfectionism, the more adaptively the coping strategy that correlates with it. In Table 5, we see a close relationship between other-oriented and cognitive coping strategies and a less close relationship with emotional coping strategies. It should be borne in mind that general perfectionism includes pathological one, and in Table 5 only selfcentered perfectionism turned out to be sensitive. Based on this, we can argue about the obtained connections as low-value and, possibly, not reliable enough. Other methods of coping strategies and differentiations of perfectionism need to be investigated for interconnection in order to boldly claim the existence of these links. More sensitive diagnostic tools and longue studies are probably needed. Mann-Whitney's U-test showed no statistical differences between boys and girls. When examining the correlation between Hewitt-Flett multivariate perfectionism scale and D.A. Leontiev SGO test, we obtained new empirical data presented in Table 6. 
Table 6. Correlation analysis of the multidimensional scale of Hewitt-Flatt perfectionism and D.A. Leontiev's SGO test

\begin{tabular}{||ccccc||}
\hline \multicolumn{5}{|c|}{ Spearman's correlation coefficients of the Hewitt-Flatt multidimensional perfectionism scale } \\
and D.A. Lentieva's SGO test
\end{tabular}

* statistically significant $(\mathrm{p} \leq 0.1)$

$* *$ statistically significant $(\mathrm{p} \leq 0.05)$

We allow these results of correlation studies to be interpreted as follows. The A.A. Zolotareva differential perfectionism test turned out to be more sensitive to the LMS test: the level of normal perfectionism correlates across all LMS sub-scales, except for life performance, to varying degrees; level of pathological perfectionism naturally has the return correlation of also different degree of expressiveness with the indicators revealed by SGO technique except, however, a control locus, the general level of perfectionism has no relationship with any sub-scale of FMS, which also seems logical to us, since the general level of perfectionism reflects only the sum of the first two and, therefore, randomly and illegally reflects in itself a different relationship of norm and pathology. When studying the correlation between the indices of the A.A. Zolotareva differential test and the D.A. Leontiev SGO test, we obtained new empirical data presented in Table 7.

Table 7. Correlation analysis of A.A. Zolotareva's differential perfectionism test and D.A. Leontiev's SGO test

\begin{tabular}{||ccccccc||}
\hline \multicolumn{7}{|c||}{$\begin{array}{c}\text { Spearman's correlation coefficients of the differential test of perfectionism: } \\
\text { A.A. Zolotareva and D.A. Leontiev's SGO test }\end{array}$} \\
\hline & $\begin{array}{c}\text { The purpose } \\
\text { of life }\end{array}$ & Life process & $\begin{array}{c}\text { Life } \\
\text { performance }\end{array}$ & $\begin{array}{c}\text { Locus of } \\
\text { control }\end{array}$ & $\begin{array}{c}\text { Locus of } \\
\text { life control }\end{array}$ & $\begin{array}{c}\text { General indicator } \\
\text { of SGO }\end{array}$ \\
$\begin{array}{c}\text { Normal perfectionism } \\
\text { Pathological }\end{array}$ & $.412^{*}$ & $.504 * *$ & .188 & $.479 *$ & $.337^{* *}$ & $.388^{*}$ \\
$\begin{array}{c}\text { perfectionism } \\
\text { General } \\
\text { perfectionism }\end{array}$ & $.323^{* * *}$ & $.407 *$ & $.389 *$ & .273 & $.456^{*}$ & $.368^{*}$ \\
\hline
\end{tabular}

* statistically significant $(\mathrm{p} \leq 0.05)$

** statistically significant $(\mathrm{p} \leq 0.01)$

$* * *$ statistically significant $(\mathrm{p} \leq 0.1)$

We allow these results of correlation studies to be interpreted as follows. Tables 6 and 7 show the correlations of the results of the perfectionism procedures and the LFR test of D.A. Leontiev.

As we see in the Hewitt-Flett scale, sensitivity again showed the "orientation to others" sub-scale, which has a moderate inverse relationship with goalsetting and also an inverse, but already tendency, with the locus of control of Self - that is, with faith in its forces to achieve life's goals. Such a result seems logical and logical to us. Mann-Whitney's Utest showed no statistical differences between boys and girls.

\section{Conclusions}

In summarizing our study, we would like to highlight the following conclusions:

- Transpective analysis of sources made it possible to assert that perfectionism has a complex structure, including a diverse orientation, functionality and causality. In medicine, conductionism is considered from the maladaptive side, and in age psychology, personality psychology, it takes place to be normal, adaptive in its manifestation in the structure of the personality.

- System of human meanings and values is connected with any aspect of individual life. Personality sense fields act as open systems capable of projecting their capabilities, 
predictions, errors, distortions. Personality responds to these projections only when it all has a profound meaning for it.

- When comparing the detected data of the level of perfectionism and the level of psychological barriers of the personality, we were able to identify the following picture of trends: the stronger the personality places demands on others, the stronger its barriers are expressed, and vice versa, the more "normal" the perfectionism of the personality, the less the barriers are expressed.

- Correlation analysis found that indicators of normal or high meaning-life orientation have direct correlation relationship with values of normal perfectionism; indicators of low meaning-life orientation have inverse correlation relationship with normal values of perfectionism.

- Analysis of values identified by Hewitt-Flett multivariate scale by means of correlation analysis with the indicators of the SGO test by D. Leontiev found that only one sub-scale "orientation to others" is clearly distinguished, nevertheless it is in moderate statistical relations with other values.

- We found that the indicator "self-orientation" is expressed only in its negative manifestation, as something inhibiting personal development and encouraging the development of psychological barriers. That is, "self-orientation" or more precisely, excessive self-orientation, can be considered as a pathological form of perfectionism.

- In our study we confirmed the presence of valuemeaning barriers in our respondents and their negative impact on the eponymous sphere of personality. The study demonstrated that cheerful, committed and responsible individuals have a lower level of psychological barriers.

- Adaptivity of selecting coping strategies may depend on the general level of perfectionism and the level of demanding for other people.

When comparing the detected data of the level of perfectionism and the level of psychological barriers of personality, no statistical differences between young men and girls were found.

\section{References}

[1]. Yasnaya, V. A., \& Enikolopov, S. N. (2007). Perfectionism: history of research and current state of the problem. Voprosy psikhologii, (4), 157-168.

[2]. Adler, A. (2013). The practice and theory of individual psychology (Vol. 133). Routledge.

[3]. Abakumova, I. V., Ryadinskaya, Ye. N., \& Golubova, V. M. (2017). Sistemno-strukturnyy analiz teoriy psikhologicheskikh transformatsiy lichnosti. Rossiyskiy psikhologicheskiy zhurnal, 14(1), 10-24. DOI: $10.21702 / \mathrm{rpj} .2017 .1 .1$
[4]. Clark, M. A., Lelchook, A. M., \& Taylor, M. L. (2010). Beyond the Big Five: How narcissism, perfectionism, and dispositional affect relate to workaholism. Personality and Individual differences, 48(7), 786-791.

[5]. Frost, R. O., Turcotte, T. A., Heimberg, R. G., Mattia, J. I., Holt, C. S., \& Hope, D. A. (1995). Reactions to mistakes among subjects high and low in perfectionistic concern over mistakes. Cognitive Therapy and Research, 19(2), 195-205.

[6]. Burns, D.D. (1999). Feeling good: The new mood therapy (Rev. ed.). New York: Avon.

[7]. Hewitt, P., Flett, G., Sherry, S., Habke, M., Parkin, M., Lam, R., ... \& Stein, M. (2003). The Interpersonal Expression of Perfection: Perfectionistic SelfPresentation and Psychological Distress. Journal of Personality and Social Psychology,84(6), 13031325.

[8]. Kruglanski, A. W., Shah, J. Y., Pierro, A., Mannetti, L., Livi, S., \& Kosic, A. (2002). The closing of the "group mind" and the emergence of groupcentrism. Society of Experiential Social Psychology, Columbus, $\mathrm{OH}$.

[9]. Ermolaeva, E. P. (2016). Dinamika lichnosti v usloviyakh marginalizatsii professional'nogo bytiya. Psikhologicheskie issledovaniya lichnosti: istoriya, sovremennoe sostoyanie, perspektivy, 311326.

[10]. Ulanovsky, A. M. (2009). Constructivism, radical constructivism, social constructionism: The world as interpretation. Voprosy psikhologii, (2), 35-45.

[11]. Horney, K. (1994). The neurotic personality of our time. WW Norton \& Company.

[12]. Rasskazova, Ye. I., Yemelin, V. A., \& Tkhostov, A. SH. (2019). Kognitivnyye komponenty radikal'nykh ustanovok i gotovnosti k ekstremal'nomu povedeniyu: razrabotka rabochey modeli. Psikhologicheskiye issledovaniya, 12(63), 2.

[13]. Novak, M., \& Highfield, R. (2010). Super cooperators. Altruism, evolution and human behaviour or why we need each other to succeed. Free Press.

[14]. Voskresensky, A. A., Rabosh, V. A., \& Sunyagina, A. G. (2018). Post-material values of generation $\mathrm{Z}$ on the way to the knowledge society-to pose the problem. J. Soc. Environ. Dev, 1, 84-87.

[15]. Franche, V., Gaudreau, P., \& Miranda, D. (2012). The $2 \times 2$ model of perfectionism: A comparison across Asian Canadians and European Canadians. Journal of Counseling Psychology, 59(4), 567.

[16]. Sniehotta, F. F. (2009). Towards a theory of intentional behaviour change: Plans, planning, and self-regulation. British journal of health psychology, 14(2), 261-273.

DOI: 1.1348 / $135910708 X 389042$

[17].De Grada, E., Kruglanski, A. W., Mannetti, L., \& Pierro, A. (1999). Motivated cognition and group interaction: Need for closure affects the contents and processes of collective negotiations. Journal of Experimental Social Psychology, 35(4), 346-365. 
[18]. Frankl, V. E. (2004). Man's search for meaning: The classic tribute to hope from the Holocaust. Random House.

[19]. Vasiliev, I.A., Popluzhnyj, V.L., \& Tikhomirov, O.K. (1980). Emotions and thinking. Moscow: Moscow University publishing house.

[20]. Webb, T. L., \& Sheeran, P. (2006). Does changing behavioral intentions engender behavior change? A meta-analysis of the experimental evidence. Psychological bulletin, 132(2), 249.

DOI: 10.1037 / 0033-2909.132.2.249

[21]. Fromm, E. (2013). Man for himself: An inquiry into the psychology of ethics (Vol. 102). Routledge.

[22]. Osipova, A. A., \& Zelenov, A. A. (2015). Kontsept «Smyslovyye bar'yery v obuchenii studentov» V sovremennom nauchno-pedagogicheskom diskurse. Rossiyskiy psikhologicheskiy zhurnal, 12(4), 78-86. DOI: $10.21702 /$ rpj.2015.4.6

[23].Zorina, Ye. S., \& Zelenov, A. A. (2016). Psikhologicheskiye osnovy smyslotekhnik kak sovremennykh obrazovatel'nykh metodov. Rossiyskiy psikhologicheskiy zhurnal, 13(1), 76-84.

[24].Alekseeva, O. S., \& Rzhanova, I. E. (2019). Values and their relationship with basic personality traits. Psychological research, 12(63), 10-30.

[25]. Klochko, V. E. (2013). Ontology of sense and senseformation (Reflections on the anniversary of $\mathrm{OK}$ Tikhomirov). Moscow University Psychology Bulletin, 106-120.
[26]. Leontiev, D. (2012). Positive psychology: An agenda for the new century. Psychology. Journal of Higher School of Economics, 9(4), 36-58.

[27]. Maddi, S.R. (2005). Meaning formation in the decision-making process. Psikhologicheskiy Zhurnal, 26(6), 87-101.

[28]. Orlov, A. A. (2016). Strategiya razvitiya pedagogicheskogo obrazovaniya: tsennosti i smysly. Pedagogika, (6), 118-123.

[29]. Shuvalov, A. V. (2011). Antropologicheskiy podkhod $\mathrm{k}$ probleme psikhologicheskogo zdorov'ya. Voprosy psikhologii, (5), 3-16.

[30].Zolotareva, A. A. (2018). Brief Differential Perfectionism Inventory: Checking Cross-Cultural Stability of the Factor Structureand Psychometric Characteristics. Cultural-historical psychology, 14(1), 107-115. DOI: $10.17759 / \mathrm{chp} .2018140112$

[31].Heim, E. (1988). Coping and psychosocial adaptation. Journal of mental health counseling, 10, 136-144.

[32]. Massanov, A. V. (2014). Psykholohichni bariery u profesiinomu samovyznachenni osobystosti [Psychological barriers in the professional selfidentification of the individual]. Psykholohiia $i$ suspilstvo-Psychology and Society, 2, 73-89.

[33]. Campbell, D. T. (1958). Common fate, similarity, and other indices of the status of aggregates of persons as social entities. Behavioral science, 3(1), 14. 